\title{
THE IMPACT OF BARRIERS INSIDE A HERRINGBONE MILKING PARLOUR ON EFFICIENCY OF THE VENTILATION SYSTEM*
}

\author{
Piotr Herbut, Sabina Angrecka, Grzegorz Nawalany \\ Department of Rural Building, University of Agriculture, Al. Mickiewicza 24/28, 30-059 Kraków, \\ Poland \\ Corresponding author: p.herbut@ur.krakow.pl
}

\begin{abstract}
The research aimed at establishing the pattern of air movement inside a $2 \times 10$ herringbone milking parlour equipped with supply mechanical ventilation. Observations and analyses were made for the streams of air supplied to the parlour, their movement pattern and spread range. Also, temperature and relative air humidity after and before evening milking routine were measured. It has been concluded that barriers installed inside the milking parlour play a significant role in creating unfavourable microclimatic conditions during milking, particularly for the last group of cows. The study points out possible threats to animal welfare and operator's working conditions. Based on the conducted experiments, the paper defines recommendations for proper design of ventilation systems inside herringbone milking parlours.
\end{abstract}

Key words: welfare, milking parlour, mechanical ventilation, air velocity

Development of research on optimising cow welfare conditions has been mainly triggered by the need to increase the profitability of cattle production. New recommendations regarding cattle production have obliged breeders to modernize barns built in the years 1960-1990. What was particularly emphasised was the need to create or improve milking areas. Herringbone milking parlour is the most popular parlour type in Poland, because it does not require a large space and is relatively easy to modify (Romaniuk et al., 2005).

The total time a cow spends in the milking area may vary depending on the number of milking routines per day. Usually, the average length of milking is between 8 to 10 minutes and it is conducted 2 or 3 times per day (every 12

\footnotetext{
* This work was financed from Department of Rural Building statutory activity.
} 
or 8 hours). Timewise, cows spend only a short period of time inside the milking parlour, therefore it is generally assumed that indoor conditions are not significant in terms of cow welfare. According to common presumptions, milking will be successful if the facility is well-ventilated and it has been equipped with proper machinery; if a good milking routine has been established; and if the operator works in a proper and comfortable way (Turner and Chastain, 1995; Munksgaard, 2001).

However, cows that are milked in the last technological group are already anxious and tired when they enter the milking parlour from the holding area. Milking routine increases sweat production and breathing frequency, consequently leading to the increase of inside air temperature and relative air humidity. If the parlour is not adjusted for the so-called fast exit from the milking stalls, the time animals spend inside the milking area increases unnecessarily. In large farms, milking is handled in several technological groups, which leads to gradual deterioration of temperature and humidity conditions inside the milking parlour as subsequent groups pass through the building. Also operator workplace comfort is decreasing in the course of the milking session.

Positive pressure ventilation system supplies fresh air from the outside through inlet fans installed in the side wall. Fans supply fresh air to the milking parlour, where the air is mixed creating pressure, which pushes out the contaminated air through gravitational outlets located, for example, on the roof (Gooch and Bickert, 1999). Such a ventilation system should ensure continuous air exchange inside the milking parlour so that temperature and relative humidity of air do not increase excessively, which could decrease cow welfare, worsen operator's working conditions and cause thermal stress, especially in the summer season (Spiers et al., 2004; Zähner et al., 2004).

\section{Material and methods}

The research aimed at determining the impact of barriers (positioning the cows during milking) and partitions (dividing the return lane from milking stalls) on the movement of air supplied into the milking parlour. The study included measurements of the following parameters: velocity, direction and spread range of supplied and exhaust air, temperature and humidity of air before and after milking.

Field studies were conducted in June and July 2010 in a $2 \times 10$ herringbone milking parlour, located in a free stall barn for 176 dairy cows at a cattle farm in the village of Kobylany, the Małopolska region.

The dimensions of the milking parlour were as follows: width: $7.15 \mathrm{~m}$, length: $12.95 \mathrm{~m}$. The milking area was located in the south-eastern part of the barn (Figure 1). The height of the parlour equalled $2.81 \mathrm{~m}$ when measured from the floor level and $3.71 \mathrm{~m}$ from the level of milker's pit (Figure 2). 


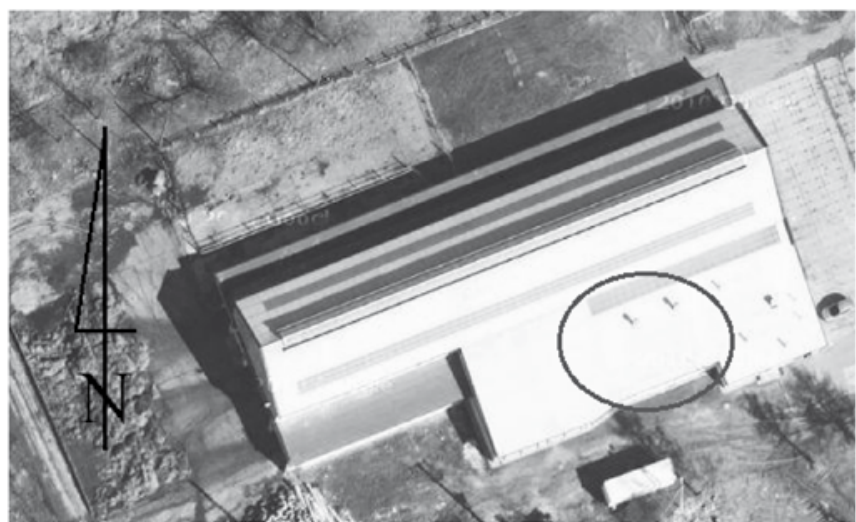

Figure 1. Location of the milking parlour inside the cattle barn (www.maps.google.pl)

a)

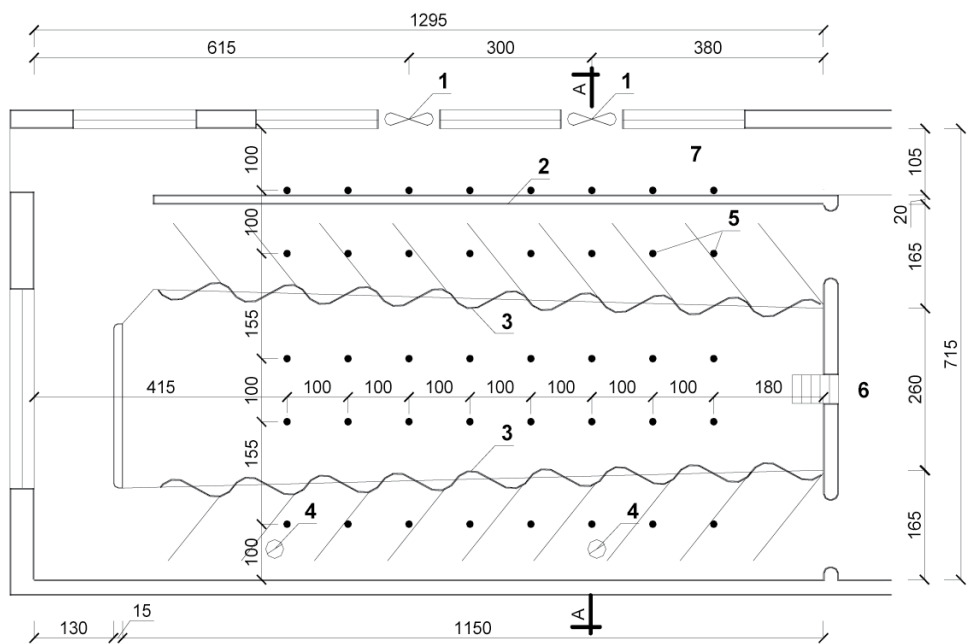

b)

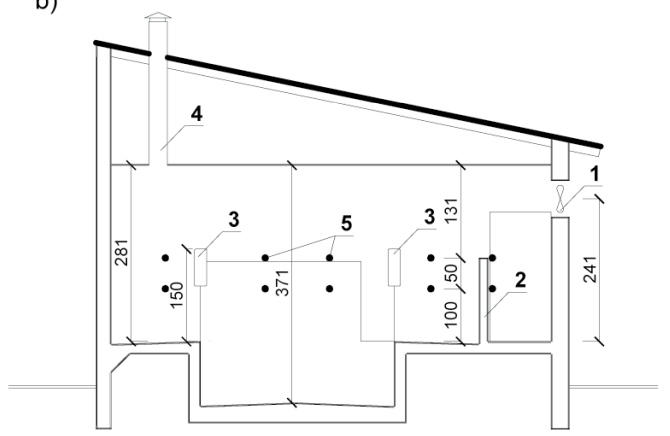

Figure 2. Projection view of the milking parlour in Kobylany: a - horizontal projection, $\mathrm{b}$ - cross-section A-A; 1 - inlet fan with blinds, 2 - partition wall dividing the milking area from the return lane, 3 - barrier positioning the cows during milking, 4 - roof outlet openings, 5 - measurement points, 6 - holding area, 7 - return lane (own source) 


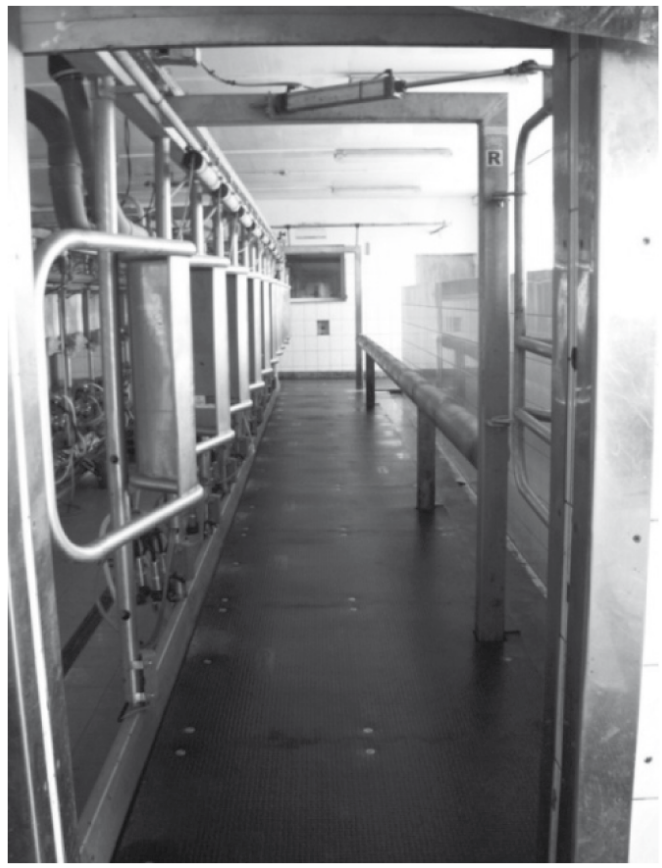

Figure 3. Barriers positioning the cows as seen from the milking lane and the partition of the return lane (on the right) (Photo: S. Angrecka)

Entrance to each of the two rows of milking stalls from the holding area led through a gate. The return lane was located along the longitudinal outside wall of the building. It was divided from the milking area by a partition wall of $150 \mathrm{~cm}$ in height. During milking, cows were positioned inside the stalls with the help of barriers, typical for this kind of milking parlours (Figure 3).

The building was equipped with a positive pressure mechanical ventilation system. The part responsible for air supply included two wall fans type $\mathrm{S}$ produced by Wentech (power: $0.25 \mathrm{~kW}$, diameter: $40 \mathrm{~cm}$, maximum efficiency: $5600 \mathrm{~m}^{3} \cdot \mathrm{h}^{-1}$ ) with blinds. The fans were installed on the southern wall at the height of $241 \mathrm{~cm}$ above floor level to their axis. The part responsible for air exhaust included two outlet openings, $30 \mathrm{~cm}$ in diameter each, located in the roof (Figure 4). All parts of the ventilation system (holes of air inlet and air exhaust ducts) were clean.

The cows were milked two times a day: at 5 am and $5 \mathrm{pm}$. Taking into consideration the time spent on bringing subsequent cow groups from the holding area to the milking parlour and the return lane, total milking time was 2.5-3 hours. There were approx. 160 cows in the barn divided into 3 technological groups. The milking routine was handled by one operator.

Air flow inside the parlour was monitored by observing the movement of smoke from smoke generators, registered electronically. Also momentary measurements of air flow direction and velocity (Windmaster 2) as well as temperature and relative air 
humidity (hygrometer-thermometer HD8901) were conducted. The measurements were performed at two levels and in two cross-sections, before and after evening milking. Outside air temperature was registered as well.

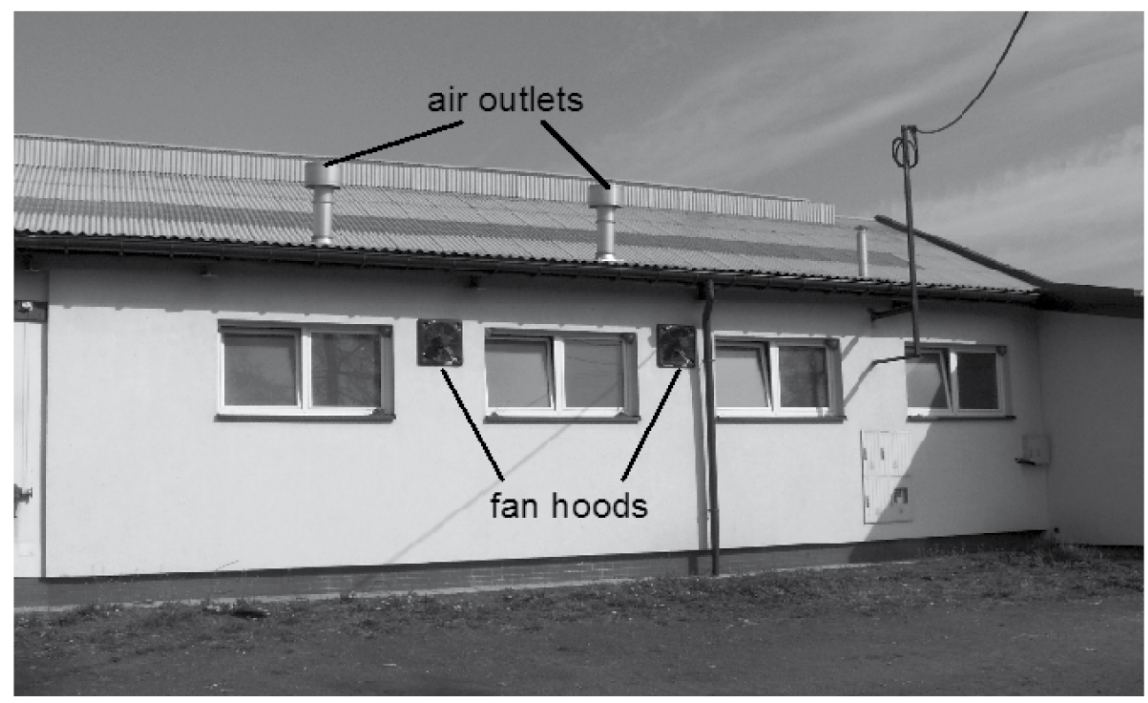

Figure 4. Fan hoods and air outlets of the milking parlour in Kobylany (Photo: S. Angrecka)

\section{Results}

Temperature and relative humidity measurements, conducted in the first days of July before evening milking at approx. $5 \mathrm{pm}$, revealed that air temperature inside the milking parlour was lower than outside temperature by $0.5-1.5^{\circ} \mathrm{C}$. Generally, the temperature remained in the range $16.9-18.2^{\circ} \mathrm{C}$. Relative indoor air humidity was similar to outdoor air humidity: between 58.6 and $62.5 \%$. By the time the first 20 cows had been milked, that is around 5:15 pm, indoor air temperature had risen to $23-25^{\circ} \mathrm{C}$ and relative air humidity had increased to $85-90 \%$. After milking, that is after approx. 3 hours, air temperature inside the milking parlour was highest and reached $27-28^{\circ} \mathrm{C}$; relative humidity soared to $93-96 \%$. It was also noticeable that air temperature in the southern near-wall zone was slightly different than in the northern one. The temperature in the latter part was higher by 0.5 to $1.5^{\circ} \mathrm{C}$. As a consequence, the last group of cows experienced the least favourable milking conditions. Some of the cows in this group even panted.

The velocity of air supplied by the fan working with maximum efficiency equalled $8 \mathrm{~m} \cdot \mathrm{s}^{-1}$. At the same time, the velocity of air movement in the southern lane was within the range $0-3.5 \mathrm{~m} \cdot \mathrm{s}^{-1}$. It is worth noting that the highest velocity was observed along the fan axis. $1.0 \mathrm{~m}$ from the fan axis, the velocity of air movement fell to $1.5-2 \mathrm{~m} \cdot \mathrm{s}^{-1}$; and with the distance increasing to $1.0 \mathrm{~m}$, it decreased to $0.1 \mathrm{~m} \cdot \mathrm{s}^{-1}$. 
The fans installed in the wall of the milking parlour were located close to each other (300 cm distance); as a result streams of supplied air interrupted each other causing turbulences in the southern row of milking stalls. Air velocity was variable and ranged between 0.1 and $0.3 \mathrm{~m} \cdot \mathrm{s}^{-1}$ (Figure 5).

a)
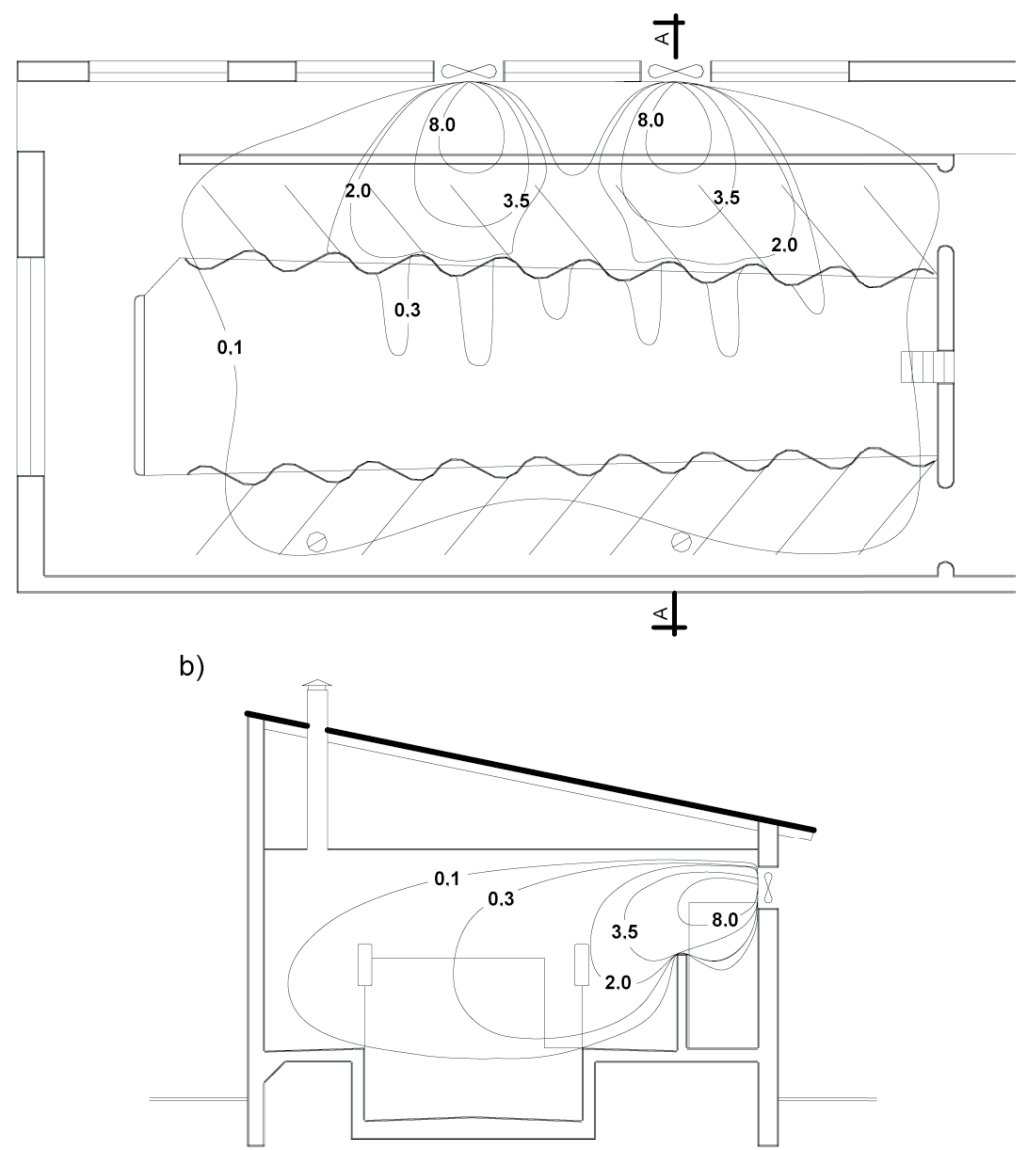

Figure 5. Pattern of velocity of ventilated air movement $\left(\mathrm{m} \cdot \mathrm{s}^{-1}\right)$ inside the milking parlour on 8 July 2010 at 4:40 pm: a - horizontal projection at the height of $130 \mathrm{~cm}, \mathrm{~b}$ - cross-section A-A (own source)

In the northern lane, air velocity measurement was only possible along the axis of inlet fans. The stream of air supplied by the fan lost its momentum suddenly on the return lane partition wall and on barriers positioning the cows at the milker's pit. The assumed velocity of air in the milker's pit and in the northern row did not exceed $0.1 \mathrm{~m} \cdot \mathrm{s}^{-1}$. The stream of air which collided with the barrier, turned towards the partition wall dividing the parlour from the return lane. However, it needs to be noted that cows were not present inside the milking parlour during the experiment. The 
animals would constitute an additional barrier for the movement of air flux towards the northern milking stalls (Figure 5).

Several experiments with the use of smoke (15 repetitions) conducted with maximum fans efficiency (for summer period) gave more comprehensive information on the movement of supplied air stream. Air streams reaching the level of $1.5 \mathrm{~m}$ reflected from the barriers and directed the smoke along the southern lane and towards the wall dividing the parlour from the return lane. Air turbulences occurring as a result of air dispersion at the first row of barriers caused gradual widening of the stream of smoke just behind the milker's pit. Consequently, the smoke penetrated through the barriers. The existing outlet openings in the ceiling did not work effectively. The smoke moved towards the holding area along the return lane and the southern row of milking stalls (Figure 6). Part of the air penetrated through openings in the barriers creating local turbulences over the milker's pit. The air stream movement was slowed down and after penetrating through the second row of barriers, it came to an almost complete standstill. As a result, the air above the northern row of milking stalls did not move at all.

a)

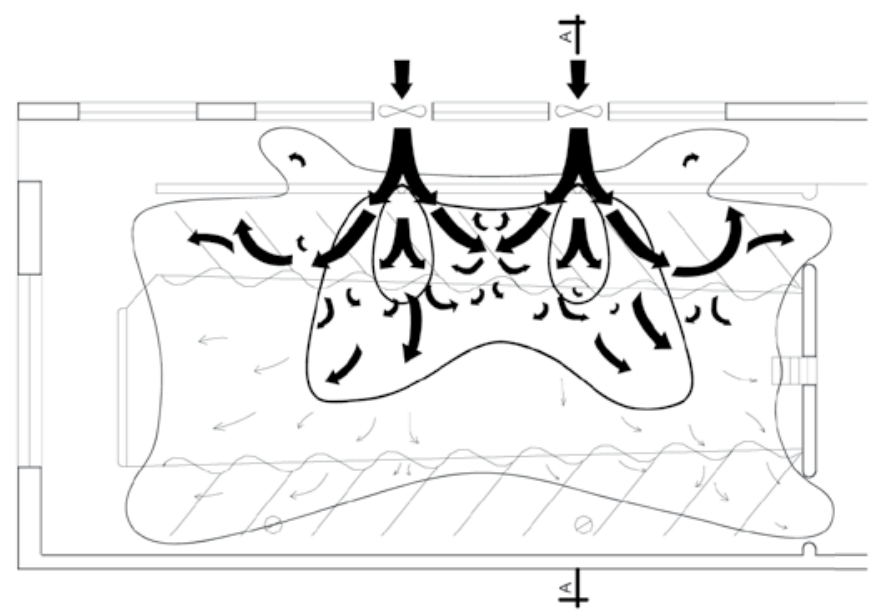

b)

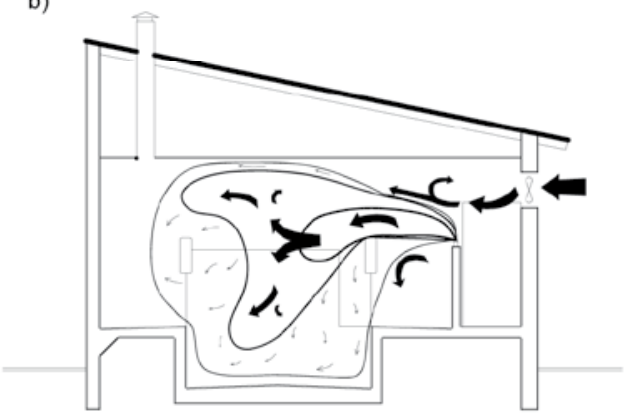

Figure 6. Distribution of smoke from smoke generators inside the milking parlour on 7 July 2010 at $4 \mathrm{pm}$ : a - horizontal projection, $\mathrm{b}$ - cross-section A-A (own source) 


\section{Discussion}

A number of past studies has been devoted to the microclimate of free stall barns, especially in the context of cattle welfare (Albright and Timmons, 1984; Cook et al., 2005; De Palo, 2006; Herbut, 2010) or working environment (Reppo et al., 2004). Specialist literature dealing with the issue of dairy cattle welfare in most cases tries to define recommended microclimatic conditions for free stall barns. The recommendations are usually limited to the definition of optimal air temperature and relative air humidity, which is regulated with the help of mechanical ventilation systems. For an adult cow, the efficiency of the mechanical ventilation system in the summer period should equal between 350 and $400 \mathrm{~m}^{3} \cdot \mathrm{h}^{-1} \cdot$ head $^{-1}$ (Romaniuk et al., 2005). According to Arnold and Veenhuizen (1994), it ranges from 60 to approximately $570 \mathrm{~m}^{3} \cdot \mathrm{h}^{-1} \cdot$ head $^{-1}$, depending on weather type. Another range for ventilation efficiency has been determined by Bickert (2000), according to whom it should remain between 85 and $800 \mathrm{~m}^{3} \cdot \mathrm{h}^{-1}$ for a cow of $635 \mathrm{~kg}$. However, compared to other sources, these values seem to be slightly underestimated.

The designers of ventilation systems for milking parlours most often take into consideration the efficiency of fans, which enable the exchange of air appropriate for the given size and population density of the building.

However, in light of the conducted experiments, it seems that designing such a ventilation system without taking into consideration the existence of different air velocity zones may have a negative influence on both cattle welfare and operator's working conditions. Additional factors include draughts or air standstills occurring occasionally (Wathes et al., 1983). Maintenance of constant conditions of air movement in the summer is particularly important because in our climate there occur high temperatures and large fluctuations of relative humidity, which can contribute to the formation of heat stress in cows (Romaniuk et al., 2005).

Herringbone milking parlours are always equipped with barriers positioning cows during milking. Together with cattle bodies, these barriers create obstacles which prevent efficient supply of fresh air with the velocity suitable for summer and winter periods (Tuure, 2003).

Therefore, it would seem justifiable to verify whether ventilation systems applied for herringbone milking parlours are optimal for these types of buildings. So far, the main criterion has been whether the system is capable of supplying a suitable amount of air inside the building. The choice made on the basis of this criterion may not only be inefficient but also dangerous. Suitable amount of air is supplied inside the milking parlour when the fans work with highest efficiency, which also means that the air stream velocity is at the top value. As a result, air stream velocity in some areas of the milking parlour is too high, which is definitely unfavourable to animals, even if we take into consideration that they stay inside for a short period of time. The appearance of zones of high air velocity may cause excessive cooling of animal bodies, breathing difficulties, udder inflammation and digestion problems (Janeczek et al., 1995).

The situation is particularly dangerous when the last group of cows enters the milking parlour, because at that time, the temperature inside the building is already 
high, so is relative air humidity. In the researched milking parlour, by the time the first 20 cows had been milked, indoor air temperature ranged between 23 and $25^{\circ} \mathrm{C}$; relative air humidity increased to $85-90 \%$, which according to Romaniuk et al. (2005) who recommend maintaining the range of $60-80 \%$, had exceeded the proper values and contributed to the development of thermal stress (Dikmen et al., 2008; Dikmen and Hausen, 2009; Silvestre et al., 2009). These parameters gradually deteriorated as subsequent cow groups entered the milking parlour.

A negative impact of barriers on air flow conditions in the milking parlour, which may contribute to the deterioration of microclimate parameters and adversely affect the microclimate conditions, was stated.

The pattern of velocity of supplied air inside a herringbone milking parlour was very changeable. Along the northern row of milking stalls, the velocity of air stream was too low when compared to values recommended for the summer season. Along the southern lane, however, the velocity was too large.

Air movement inside the milking parlour was significantly disturbed by the partition wall dividing the return lane from the row of milking stalls and barriers positioning the cattle. The partition reduced the velocity of air supplied by the fan, which significantly limited the scope of supplied air.

The designers of ventilation systems for herringbone milking parlours should pay more consideration to barriers and partitions inside the building and disturbing the flow of air. The situation may be partly improved by installing fan blinders which would direct the air stream towards the ceiling. As a result, the air stream directed upwards would omit the barriers and partitions. Consequently, the scope of fresh air distribution would be wider, thus preventing excessive cooling of cow bodies. However, it seems that milking parlours of this type would work most efficiently if they were equipped with positive pressure ventilation systems with inlet fans installed on the roof of the building.

\section{References}

A 1 b rig h t L.D., T i m m on s M.B. (1984). Behavior of dairy cattle in free stall housing. Trans. ASAE 27: $1119-1126$.

Arnold G.J., V e e n hu i ze n M.A. (1994). Livestock Housing Ventilation Fan Selection. Ohio State Cooperative Extension Factsheet. Columbus, Ohio: The Ohio State University.

B i c k e r t W.G. (2000). Dairy freestall housing and equipment. MidWest Plan Service Iowa State University, 7 th ed., p. 3

Cook N.B., B e nnett T.B., N ordlund K.V. (2005). Monitoring indices of cow comfort in freestall-housed dairy herds. J. Dairy Sci., 88 (11): 3876-3885.

De Palo P., Tateo A., Zezza F., Corrente M. Centoducati P. (2006). Influence of freestall flooring on comfort and hygiene of dairy cows during warm climatic conditions. J. Dairy Sci., 89 (12): 4583-4595.

Dikmen S., A lava E., Pontes E., Fear J.M., Dikmen B.Y., Olson T.A., Hans en P.J. (2008). Differences in thermoregulatory ability between slick-haired and wild-type lactating Holstein cows in response to acute heat stress. J. Dairy Sci., 91: 3395-3402.

D i k m e n S., H a n s e n P.J. (2009). Is the temperature-humidity index the best indicator of heat stress in lactating dairy cows in a subtropical environment? J. Dairy Sci., 92: 109-116. 
G o o c h C.A., B i c k e r t W.G. (1999). Ventilation Strategies for Environmental Control of Modern Milking Centers. ASAE Annual International Meeting, ASAE Paper No. 994013. ASAE 2950 Niles Road, St. Joseph.

Herbut P. (2010). Air movement characteristics inside a cow barn with natural ventilation under no-wind conditions in the winter season. Komisja Techniczna Infrastruktury Wsi PAN oddział w Krakowie, 11: 159-164.

Janeczek W., Chudoba-Drozdowska B., Samborski Z., Kusz A. (1995). Skin temperature changes of the cow mammary gland and the heat flux from its surface before and after milking. Arch. Vet. Pol., 35: 35-44.

Munksgaard L., de Passille A.M., Rushen J., Herskin M.S., Kristensen A.M. (2001). Dairy cows' fear of people: social learning, milk yield and behaviour. Appl. Anim. Behav. Sci., 73 (1): 15-26.

Reppo B., M iks on E., V a a rak V. (2004). Relation between the indoor and outdoor climate in uninsulated cowsheds. J. Agric Sci., 17 (2): 120-125.

Romaniuk W., Overby T. (2005). Systems of maintenance of cattle. Reference book. Praca zbiorowa. Projekt Bliźniaczy PHARE, Standardy dla Gospodarstw Rolnych. Warszawa: Instytut Budownictwa, Mechanizacji i Elektryfikacji Rolnictwa; Duńskie Służby Doradztwa Rolniczego, pp. 43-5, 172 .

Silvestre F.S., Kamimura S., Arteche A.C., Bartolome J., Pancarci S.M., That c h e r W.W. (2009). Reproductive responses following postpartum suppression of ovarian follicular development with a deslorelin implant during summer heat stress in lactating dairy cows. Anim. Rep. Sci., 111: 320-337.

S p i e r s D.E., S p a i n J.N., S a m p s o n J.D., R h o a d s R.P. (2004). Use of physiological parameters to predict milk yield and feed intake in heat-stressed dairy cows. J. Therm. Biol., 29: 759-764.

T u r n e r L.W., Ch a s t a i n J.P. (1995). Environmental Control in the Milking Center. In: Designing a Modern Milking Center, NRAES-73, NRAES, Cooperative Extension, 152 Riley-Robb Hall, Ithaca, NY, pp. 141-153.

T u u r e V.M. (2003). Cold working environments on dairy farms in Finland. Int. J. Circumpol. Heal., 62: 190-203.

W a the s C., J o ne s C., W e b s ter A. (1983). Ventilation, air hygiene and animal health. Vet. Rec. 113: 554-559.

Zähner M., S chrader L., Hauser R., Ke ck M., Langhans W., We chs ler B. (2004). The influence of climatic conditions on physiological and behavioural parameters in dairy cows kept in open stables. Anim. Sci., 78: 139-147.

Accepted for printing 17 IV 2012

PIOTR HERBUT, SABINA ANGRECKA, GRZEGORZ NAWALANY

Wpływ wygrodzeń hali udojowej typu „rybia ość” na skuteczność wentylacji

\section{STRESZCZENIE}

Celem pracy było zbadanie rozkładu ruchu powietrza w hali udojowej typu „rybia ość” $2 \times 10$ z wentylacją mechaniczną nawiewną. Obserwacjom i analizie poddane zostało kształtowanie się strug powietrza nawiewanego do hali i ich zasięg. Określono również temperaturę i wilgotność względną powietrza przed i po doju wieczornym. Stwierdzono bardzo duży wpływ elementów wygrodzeń hali udojowej na tworzenie niekorzystnych warunków mikroklimatycznych w trakcie doju, zwłaszcza dla ostatniej grupy krów. Wskazane zostały zagrożenia dla dobrostanu zwierząt podczas doju oraz komfortu pracy dojarza. Na podstawie przeprowadzonych badań określono zalecenia dotyczące projektowania systemów wentylacyjnych w halach udojowych typu „rybia ość”. 